\title{
QUEER (RE)VISIONS OF ARCHIVE, AFFECT, AND PLACE IN CHILD AND YOUTH CARE
}

\begin{abstract}
August A.
Abstract: This article presents an autoethnography that interweaves the queering of archive, affect, and place using an object-oriented method. Engaging with a hundred-year-old antique photo album found in a thrift store, this article brings forth queer (re)visions of past, present, and future that (re)imagine queer (be)longing, which expand spheres of ancestral consciousness in 2SLGBTQIAA+ communities. Situated in the United States, this work traces the entanglements in this object-oriented autoethnography through a mapping of queer identity in the Pacific Northwest, capturing temporal reflections that reach from the present back into 1918 and back further still into the early English colonies. In orienting towards the realm of queering child and youth care this work seeks to contribute to a cultivation of discourse of collective (re)visions of past, present, and future that uproots the enshrined settler-colonial, white supremacist, heteropatriarchal, capitalist ethos that continuously crafts the layered erasures of sex, gender, and sexually diverse people in the United States. I endeavour in the threading of autoethnography, both as a white settler and in my being and continually becoming, a genderqueer, trans person struggling and thriving, to critically query the implications of this history within the present and to (re)affirm the possibilities for queer and trans youth in the future.
\end{abstract}

Keywords: queer, affect, archive, lgbtq+, youth, autoethonography

August A. (they/them/theirs) is a student in the Master of Arts program at the School of Child and Youth Care, University of Victoria, 3800 Finnerty Road, Victoria, BC V8W 2 Y2. Email: augusta@uvic.ca 
International Journal of Child, Youth and Family Studies (2021) 12(3-4): 55-73

\author{
queering archive, affect, and place \\ $\sim$ through object-oriented autoethnography \\ (re)imagining \& empowering \\ queer ancestral consciousness \\ in CYC and beyond
}

In this article there are passages containing critical reflections stemming from what felt like a moment of time travel that occurred when I visited a thrift store in the suburbs of Portland, Oregon in 2016. I came upon an antique photo album that lay amongst the plastic binders, address books, and random folders. The beauty of the stark black sturdy paper against the uniquely scribed goldenyellow font pulled me in. In its pages was a photo that spoke to a place deep within me. It showed a hammock with what appeared to be two women in long dresses resting together, with heads at opposites ends and legs intertwined. The handwritten caption read "Solid Comfort' — Sheridan, OR 1918”. I was instantly carried to that moment, in a pivotal year that saw the eruption of a global influenza pandemic and the end of the First World War.

As I moved through the pages of the album, I encountered another photograph that resonated with me: a different pair, this time standing side by side, one wearing a fashionable period dress while being held at the waist by the other, who wore markedly plain attire and appeared to have been one of the young women swaying in the hammock and embodying "solid comfort" in the first photo. The apparent intimacy between the two piqued my interest in the contrasting choices of clothing between the plainly dressed young person and the person they held close. I wondered: was the plainly clothed young person purposely standing at the cusp of American society's limits for the presentation of identity for a young women in that period? I began to read the many captions preserved on the pages, including some that no longer had pictures affixed to them. There was a sense of ambiguousness that overtook me as I perused the materials, and a precious laughter filled my body as I read the words "Oh to see you smile" on an otherwise empty page. I began to imagine this plainly-clothed young person scribing their longing for the one they held close, as they marked the places that contained their moments - places familiar to me, like Portland, Oregon and Seattle, Washington.

Until that moment, I had not seen or held archival materials that dated before the mid-late 20th century that allowed me to identify and connect with a sense of ancestral belonging rooted in the existence of queer young people living beyond the norms of sex, gender, and sexuality in the United States. There was a sense of enmeshment that occurred within me, collapsing the moments that unfolded on the album's pages from 1917 to 1919 into a momentary sense of queer 
International Journal of Child, Youth and Family Studies (2021) 12(3-4): 55-73

(be)longing ${ }^{1}$ with those reimagined moments, awakening a curiosity that kindled a growing sense of queer ancestral consciousness.

\section{Queering Archive, Affect, and Place}

In her book Unruly Visions, Gayatri Gopinath (2018) charted a path of uprooting by engaging with archive, region, affect, and aesthetic through "queer optics" (p. 5). Gopinath's analysis dissolved the trepidations that had been nagging at me. Although I had reviewed numerous scholarly articles that theoretically grounded the intention, purpose, and fruitfulness of an academic container for this queering of archive interwoven with my own affective relationship through writing, I had not previously met a work such as hers, which spoke directly to the core tenets of my intended analysis while also embodying the action of queer (re)vision. In defining the realness of the "everyday archive" that holds "queer counter-archives ... minor histories ... informal archives made up of discarded and devalued objects", Gopinath helped me to know that my own emerging curiosity about, inquiry into, and entanglement with this thrown-away photo album has a place that is continuing to be carved out in academia (p. 8). Gopinath (2018) defined the queer lens as the central tenet of this analysis in stating that:

Queer desire, identification, and affiliation are central to apprehending this indiscreetness of multiple histories, spaces, and temporalities. If these aesthetic practices bring to the fore those shadow histories, subjectivities, and desires that are occluded in dominant history, queerness is the conduit through which to access the shadow spaces of the past and bring them into the frame of the present. (Gopinath, 2018, p. 9)

In a similar vein, queering can also be accessed through various forms of writing. As Dallas Baker (2013) explained in her article entitled Creative Writing Praxis as Queer Becoming, the "Queer (re)positioning of textual subjectivities in discourse as an intervention into power relations, around sexual and gender identities ... is a practice of liberty (Foucault 1978)" (p. 360). In connection to this, Esmeralda Rodriguez et al. (2017) discussed how, by using autoethnography, a writer can engage in a method of "assemblage" wherein the vast layered multiplicities of a focus area can be "juxtaposed" in such a way as to illuminate one's evolving and precarious relationship to the phenomena. Desiree Rowe (2017) reflected that the "autoethnographic mapping of the object, then, allows for us to unfold the intersections of stories and bodies" (p. 230). The queersubjective, affective relationship that is intermingled in this research is an embodiment of the process described by Baker (2013), wherein “queer becoming is a practice and/or process through

\footnotetext{
${ }^{1}$ I use "(be)longing" in this way to draw attention to the relationship between belonging and longing. Archival documents such as photos, books, and other materials that are subtly or covertly 2SLGBTQQIA+ require a lens (or vision) into the past, present, and future that embraces imagination. Queer diasporic scholar Gayatri Gopinath (2018) directly informs this articulation. I see that (be)longing, and one's desire as a queer young person to see oneself in the past, present, and future, are interconnected with the necessity to engage in archival methods with a lens of imagination and revision that illuminates the way 2SLGBTQQIA+ people have been erased. Similarly, I use "(re)vision" to highlight the need for continued, ongoing visions (imagination) across time and place.
} 
which queer subjects intervene in their identities or subjectivities and remake themselves; also, a resistant practice, a practice of liberty" (p. 360). Marika Cifor (2015) reinforced the use of affect theory, specifically in relation to archival discourse, as a tool to critically analyze "the way power circulates in discourse" (p. 7). These scholars represent guideposts for navigating the arising intimacy of this journal article's intentions, interweaving queer archival research and autoethnography while underpinning analysis with a critical lens that seeks to illuminate (re)claiming queer (be)longing for 2SLGBTQIAA+ children, youth, and families.

In queering child and youth care, we can decolonize our tenets and praxis through (re)constructing archives, affect, and place. In this article, the act of queering ancestral consciousness is an academic manifestation, a queer method of praxis, that 2SLGBTQIAA+ people of colour have been holding sacred, protecting, rekindling, and passing along since time immemorial. In my growing awareness, I acknowledge the work of adrienne maree brown, Gayatri Gopinath, Leah Lakshmi Piepzna-Samarasinha as writers and activists who trouble the white ${ }^{2}$ settler-colonial versions of archive, affect, and place to (re)claim ways of being and belonging beyond the regimes of patriarchy and white-supremacy culture by activating a reverence for and an honouring of ancestral consciousness rooted in resistance, survival, and love.

\section{(Re)Claiming}

In (re)claiming queer belonging and navigating temporal (re)visions this inquiry seeks to embody the Deleuzian concept (Gilles Deleuze, 1925-1995) of the "rhizome". In the Handbook of Autoethnography, Deanna Shoemaker (2013) refined and illustrated this concept, stating: "Embodying principles of non-hierarchical connection and heterogeneity, the rhizome calls a queer aesthetic that conjures various horizons" (p. 531). In this way, this article is an effort to queer temporality, reconfiguring my ongoing and evolving relationship with a (queer) ancestral consciousness that can exist within and beyond the biological. The article and the formal thesis inquiry that will follow aims to contribute to the lay and formal queering of ancestral narratives, in the realms of child and youth care, as a method of empowerment for 2SLGBTQIAA+ communities (re)claiming belonging and honouring the vast web of lineages that dwell outside the binary.

\section{Queering Ancestral Consciousness}

The photo album had entered my orbit in 2016, one day before the United States presidential election - a night that is seared into my memory. The curiosity piqued in that thrift store aisle

\footnotetext{
${ }^{2}$ I have chosen to not capitalize "white" in this article. The article "Why we Lowercase White" by John Daniszewski (2020) best encapsulates the reasoning behind this decision. I will continue to critically reflect and engage in dialogue and learning around race, racism, and language. In so doing, I recognize that, as Meera E. Deo (2021) stated, "Clearly, language itself (like race) is both socially constructed and fluid - constantly changing, shifting, and evolving. When using language and especially when crafting new terms to think about race, racism, and resistance, it is therefore critically important that racial categories and terminology are grounded not only in history, but in contemporary context" (p. 119).
} 
was momentary and fleeting. I had excitedly brought the treasure home with me, sharing it with my housemates, one of whom was my long-time friend and someone who has felt to me to be chosen family. As I noted the subtle queer underpinnings that appeared to me throughout the pages, she rolled her eyes. Because of her social position, she had never felt the need to search for subtext or subtlety to feel seen. In hindsight, my younger queer self was there with me, existing in a heightened state and pulsing with unresolved trauma related to gender and sexuality (alongside other complexities). Unconsciously the queer child within me had anticipated the rebuff, while still holding out for signs of safety and belonging. Instead, my friend's eyes shed doubt upon my queer interpretations and reminded me of the heartbreak of longing to be seen. The album was tucked away after this initial contact.

The album re-emerged into my consciousness nearly two years later. During this period seismic shifts in my own queer (re)claiming had taken place, including a name change and adoption of nonbinary gender pronouns, as well as connecting with a trans-focused primary care doctor. It was around this time that we welcomed in a new housemate, contacted through a queer housing social media group. I recall nervous anticipation as I brought forth the album and shared with this new housemate the queer intimacies that I had gleaned from it. On those thick dark pages, I pointed out the fading captions and images:

\section{'Oh to see you smile' \\ \& 'prunes eating prunes', photographs of \\ the hammock that held solid comfort, the young couple standing posing side by side, another moment of two young people...}

$\sim$ one standing behind the other $\sim$ arms pulling them in close $\sim$ all four hands tangled up $\sim$ As they stood donning swimsuits,

in a lake with their friends,

holding the moment for the camera, to be remembered.

When I looked up at this housemate, I was greeted with their smile of amazement that I had come upon this discarded 100-year-old queer love story. They suggested I might be able to trace the origins of the album. This affirmation rekindled in me a desire to seek out and unravel the curiosity that the archival materials had piqued, leading to a lay-archival exploration that allowed me, though not a professional archivist, to infer a persuasive, if necessarily incomplete, account of the album creators' origins. I began to scan the pages, straining to interpret the fading cursive captions on previously overlooked pages to pin down any distinguishable references or hints. In a photograph of a young man posing with a sports racket, I noted that the building in the background had an advertisement painted on the side. A generic online database search using the full text of the advertisement revealed that the building was a prominent and historically well-known Seattle 
business that is the subject of a specialized repository in a local regional museum. I also saw that nearly one-third of the album had blank pages, some holding the remnants of adhesive paste where pictures had been. When I fanned through this end-portion of the album, two partly preserved fourleaf clovers dropped out.

As I continued to engage with the album, I began to focus on metaphysical queer ancestral realms by immersing myself physically in their material landscapes. I engaged in semi-structured place-based wanderings in the locations recorded in the album, while simultaneously (re)imagining a queer narrative taking place, tapping into an embodied felt sense of the unfolding narrative. I visited historical museums and repositories, sifting through directories, maps, and special collections in search of materials that could affirm the existence of the young person clothed in the plain attire. I examined regional archived newspapers using an online database, focusing on the period of 1917 to 1919. I came upon a clipping from the Tacoma Times of Tacoma, Washington, a smaller city in the Pacific Northwest region. The headline, one that seems antiquated today, was "Woman Lives as a Man" (1917). Once again I was transported back a hundred years as I envisioned myself as the person who was being described as "living as a man". It felt extraordinary to come upon a century-old newspaper acknowledging the existence of a person living beyond the norms of sex, gender, and sexuality, a type of coverage I had not previously associated with that time period. I felt compelled to seek deeper insight into this story.

It was only at this point that curiosity began to dissolve the emotional barriers that had previously numbed any desire I might have felt to trace my biological paternal lineage. In a pivotal moment, my estranged biological father, confused about the change of my name on social media (after a significant delay of awareness), had reached out via text messages leaving a thread of awkward conclusions regarding my gender identity and ended the thread with multiple lines of sad-crying emojis. After careful consideration, I responded with an offer to exchange emails and answer questions as best I could. The email I received expressed his "love" for me and told me to "think logically" about an article he had attached, entitled "Lady Gaga Accidentally Proves Why Trannies Shouldn't be Allowed in the Military"3. I decided that withdrawal was the safest option for survival, setting and enforcing a boundary of unilateral severance.

I began to chart my biological ancestry, as well as that of the album's potential creator, by using a prominent online database ${ }^{4}$. There was an abundance of materials already pinned to people across centuries, adding depth and context to these lives that intermingled over time to form mine. Reflecting upon the bodies that have brought mine into being, alongside this (re)imagined queer ancestor, I became cognizant of our overlapping ancestral similarities. Like me, the person pictured

\footnotetext{
${ }^{3}$ After President Trump declared on Twitter that transgender people would be banned from serving in the military, popular singer Lady Gaga posted a tweet on July 26, 2017 asking if he knew that " $45 \%$ of them ages (18 to 24 ) have attempted suicide already". This was taken by many as proof that transexuals should not serve in the military. https://twitter.com/ladygaga/status/890325967595606017?lang=en
}

${ }^{4}$ Based on reasonable assumptions regarding the identity of the person in the photograph, I was able to trace a probable ancestry of that person alongside my own using https://www.ancestry.com. 
International Journal of Child, Youth and Family Studies (2021) 12(3-4): 55-73

swaying in the hammock was born near the Salish Sea as a white settler on the stolen homelands of the Duwamish and Suquamish peoples. Setting my paternal line alongside the maternal line of this queer ancestor, I began tracing the lineage of these settlers.

\section{Tracing a Regime of Patriarchy and the False Binary}

In the early 17th Century, disembarking on the lands of the Wampanoag, Massachusetts, Nipmuck, Pennacook, Penobscot, Passamaquoddy, and the Quinnipiac, the first English colonists brought with them biological and theological warfare. Integral to the present analysis is an awareness of the forces that set those ships to sail. A central role was played by the judicial framework of Christianity which issued religious proclamations of authority for " declaring war against all non-Christians throughout the world ... specifically sanctioning and promoting the conquest, colonization, and exploitation of non-Christian nations' - a collective proclamation that would later become known as the "Doctrine of Discovery" (Newcomb, 1992, p. 18, as cited in Greenberg, 2016, p. 236). One relevant decree relevant is the Papal Bull "Inter Caetera" (1493) imposed by Pope Alexander VI, which was used to “justify Christian European explorers' claims on land and waterways they allegedly discovered, and promote Christian domination and superiority, and has been applied in Africa, Asia, Australia, New Zealand, and the Americas" (Upstander Project, 2021, para. 2). These proclamations were embedded in the legal governing structures of the colonial/settler-colonial mission of conquest. In the United States and Canada this decree continues to be cited as a legal precedent for the continued disenfranchisement of Indigenous ${ }^{5}$ peoples and communities (Assembly of First Nations, 2018); it was invoked as recently as 2018 (Doctrine of Discovery, 2021).

Evelyn Nakano Glenn (2015) parsed out multiple threads of social, economic, and political authority that crafted colonization and settler-colonization, focusing on the "context of and experiences in the New World" (p. 58). The "metropole" (homeland) of Great Britain wielded the manufactured sovereign power that was granted by the Church to engage in the "settler colonial project" for the purpose of economic exploitation (Glenn, 2015, p. 58). Utilizing an intersectional analysis, Glenn (2015) framed this project as an ongoing structure in which "logic, tenets, and identities engendered by settler colonialism persist and continue to shape race, gender, class, and sexual formations into the present" (p. 55). Specifically, crafting these as hierarchical formations supported the normalizing of the racialization of whiteness, and the placing of white males at the pinnacle and white women as subservient (Glenn, 2015, p. 70). Thus, the metropole of Great Britain is a primary source for the deep-seated heteropatriarchal scripts and illusions that incite the erasure of diverse bodies and behaviours in the United States.

Silvia Federici (2004), Imani Perry (2018), and Jonathan O'Donnell (2020) each grounded their analysis of the legalized erasure of people who did not align with this regime of white-bodied patriarchy on the integral role that criminalization and demonology played in its ratification. Perry

\footnotetext{
${ }^{5}$ The capitalization of Indigenous is intentional. This usage is explained in the book Elements of Indigenous Style: A
} Guide for Writing By and About Indigenous Peoples by Gregory Younging (2018). 
International Journal of Child, Youth and Family Studies (2021) 12(3-4): 55-73

(2018) pointed to three foundational judicial concepts - sovereignty, property, and personhood - that underlay the structure of the political, economic, and social systems that sustained the patriarchal orderings in the nation-state and in "colonial incursions" (p. 21). Perry focuses on the Enlightenment political philosopher John Locke (1632-1704), illustrating a foundational concept propounded by Locke:

The doctrine of personhood - entails a system whereby the subject before the state or the law was made into either a patriarch, his liege (woman), or someone outside legal recognition, whether slaves or what in that time were termed "savages" but whom we can also term "nonpersons" in the juridical sense. (p. 21)

The implications of this for gender and sexually nonconforming people are grave because of "the naturalization of binary gender categories that were, and continue to be, applied to citizenries. Those who lie outside citizenship and the gender binary had distinct rules applied to them, which were often mechanisms for violent domination" (p. 21).

Before Perry (2018), Federici (2004) problematized the negation of nonbinary understandings of gender location in "the normative body politic of Christendom", enshrined through the centuries-long constructed sovereign authority of the Church, such that these legal mechanisms were:

manifested in the criminalization of abortion, sex work, and homosexuality, in land privatization, and the binary division of people based on ascribed biological function and their assignation to duties of productive or reproductive labor processes enacted throughout Europe and its colonies. (p. 11)

More recently, O'Donnell (2020) reflected upon the significant influence of Jean Bodin (15301596), a formative English thinker and writer in political theology, noting how Christian theology was wielded to configure the legitimization of sovereign power for the "delegitimization (indeed, demonization) of all that threaten their desire for singularity and supremacy, sentencing viable alternatives to perdition" (p. 532). This crafting of sovereign power as theopolitical is deeply and intimately intertwined in the doctrine and authority of the Church (O'Donnell, 2020, p. 531). O’Donnell (2020) noted that Boden's, Les Six Livres de la République [The Six Books of the Republic] of 1576, positioned the family as the "true image" of the state — whilst the sovereign ruler was the "image of god" - reflecting "the natural society, founded by the creator of nature himself [emphasis added] at the beginning of the human race" (O’Donnell, 2020, p. 533). This results in a societal design and ordering of common life that transforms a person's daily activities into an "imitation of the divine" (O’Donnell, 2020, p. 531). O'Donnell (2020) referred to Bodin as the "godfather of political sovereignty" and a seminal agent for embedding demonology into the legal structures of criminalization. Before O'Donnell, Perry (2018) had pointed out that the implications of these articulated specifications go deeper than legal sanctions of "rights and 
recognitions of legal personhood", in that an individual and familial relations were simultaneously infused with power differentiation and legitimization through these orderings (p. 24).

Notably, Federici (2004) and O'Donnell (2020) made evident the correlation between the emerging economic system of early capitalism and the implementation of the witch-hunt as a method of mass control; these occurred alongside a growing theological literature authored by wealthy White men. Federici (2004) examined Bodin's (1580) On the Demon-Mania of Witches in which Bodin insisted that witches should be "burned alive instead of being 'mercifully' strangled before being thrown into the flames, that they should be cauterized so that their flesh should not rot before death and that children too be burned" (as cited in Federici, 2004, p. 168). Layering their analysis of archival (re)visions, O'Donnell (2020) posited a parallel between queerness and witchcraft, recognizing that "queerness" has:

[a] dual sense used by queer theorists, to "designate a refusal or an inability to signify monolithically in relation to sex, gender, and to sexuality and that which is othered, excluded, and marked for death within normative society to maintain that society's coherence and teleological vision of the future. (Whiteneir, n.d., as cited in O’Donnell, 2020, p. 541)

These passages become intimately entangled with my ancestral connections (biological and otherwise) and the queer ancestor whose photo album has become a precious heirloom. Because I was using an online database accessed by millions of people daily, I could easily maneuver through the layers of research and historical context that may be hyperlinked to an individual ${ }^{6}$. I found that the bodies and the familial formations that had brought ours into being in the region of the Pacific Northwest were descendants of the first generation of settlers that formed the Massachusetts Bay Colony ${ }^{7}$. These forebears adhered to the strict Puritan beliefs that infused the governing structures forming all aspects of life in the colonies. This served to perpetuate the pervasive forms of violence and oppression, that underlay the enactment of political-theological sovereign power for the ultimate purpose of capitalizing on the wealth of the colonies. In the year 1692, in the Massachusetts Bay Colony, my ancestors (paternal lineage) found themselves imprisoned on charges of witchcraft, alongside the ancestors of the person I believe to be the album's creator.

In the seminal work of Jonathan Katz (1976), the erased histories of "Lesbians and Gay Men" in the United States are made visible. Michael Bronski (2011), in A Queer History of the United

\footnotetext{
${ }^{6}$ The abundance of archival materials documented on Ancestry.com is due to the legacy of colonial/settler colonial violent destruction. Church documents of births, baptisms, marriages, and the like are directly tied to the granting of legal personhood and political sovereignty. Thus, in colonial/settler colonial realms, this type of archival documentation does not exist for those deemed to be outside of political personhood. This way of seeing into the past through paper and ink (or material forms of archive as a whole) represents a hegemonic archival practice that should continue to be critically reflected upon. Queering archival methods requires honouring and opening to 2SLGBTQIAA+ ways of knowing and relating to ancestry that exist beyond the confines of conformity of white colonial/settler colonial knowledge creation.

${ }^{7}$ Personal archival materials.
} 
International Journal of Child, Youth and Family Studies (2021) 12(3-4): 55-73

States, positioned Katz's (1976) work as influential scholarship that arose out of the 1970s' gay liberation movement, signalling an "LGBT" archival (re)claiming (p. xv). Katz (1976) laid bare the compiled archival evidence of the atrocious tactics of heteropatriarchal surveillance and enforcement, stating that for the

four hundred years documented here, American homosexuals were condemned to death by choking, burning, and drowning; they were executed, jailed, pilloried, fined, court-martialed, prostituted, fired, framed, blackmailed, disinherited, declared insane, driven to insanity, to suicide, murder, and self-hate, witch-hunted [emphasis added], entrapped, stereotyped, marked, insulted, isolated, pitied, castigated and despised. (p. 11)

While there are limitations of the work's theoretical lens, as it frames sexuality and gender in a homonormative script, this volume of archival materials can be honoured as a watershed moment in queering literary history. Bronski (2011) articulated the complications that occur in archival analysis, noting that language and concepts regarding sex, gender, and sexuality are ideas created by a given cultural milieu, influenced by the epoch. Bronski (2011) noted that "while language informs identity, the elaborate emotional, psychological, and political intricacies of lives exceed identity, and language itself. There is never a perfect word or set of words to fully understand oneself' (p. xviii). However, rather than relinquish the past, Bronski (2011) encouraged the reader to see "history as an ongoing process through which we understand and define ourselves and our lives" (p. xiv). The queering of archives in the container of this inquiry shall endeavour to expand rather than contract. I shall strive to honour the agency and epoch of the figures in the photo album in a way that carves out space for malleability of bodies and behaviours while allowing for (re)visions that are affective and critique the crafted doctrines of white-supremacist, able-bodied, cisgender, heteropatriarchal conformity.

Stepping back into the archive, Peter Boag (2011) sought to query "how and why crossdressers and the transgressive sexual and gender identities they represented have been marginalized, expunged, and forgotten in Western History" (p. 8). The introductory chapter contains an "extended meditation on the life history" of Alan Hart, who, in 1918 in Portland, Oregon, underwent the first (consensual) surgical procedure that sought to affirm his "physical and sartorial transformation into a man" (p. 13). Emile Devereaux (2010) noted that while this surgery represents "the first in the United States for what would later be termed 'transexual", there were intersex individuals who underwent surgical interventions employed under the guise of "corrections" (p. 178). The erasure of sex-diverse people at the turn of the 19th century was illustrated by Gill-Peterson (2018) as:

The abstract value of the child's growing body as a guiding metaphor in the life sciences and the process through which its plasticity was brought under the jurisdiction of medicine hold our attention. Intersex children were forced during these decades into a decisive role as the experimental subjects in whose bodies the 
International Journal of Child, Youth and Family Studies (2021) 12(3-4): 55-73

abstract theories of endocrinology were translated into real medical technique for altering human sex. (p. 62)

Gill-Peterson (2018) offered insight into the historical path of modern medicine that has sculpted and pathologized bodies into categories of "inversion, hermaphroditism, homosexuality, and transvestism" as a means of constructing and upholding binary sex (p. 95).

Honouring Hart's legacy, Devereaux (2010) critiqued the "perversely voyeuristic" medical journal article that was authored by the attending doctor who published his interpretation in the Journal of Mental and Nervous Disease in 1920, entitled "Homosexuality and its Treatment" (p. 176). Devereaux re-examined Katz's (1976) placement of this article in his chapter on "Passing Women", in which Katz comments on the procedure and Hart's life with disdain, framing Hart's choices as "internalized homophobia" (p. 177). Importantly, Devereaux (2010) also cited Katz's updated perspectives: Katz has since retracted this epoch-based categorization and critique (in Booth, 2000, as cited in Deveraux, 2010, p. 177). The larger purpose of Devereaux's paper was to analyze Hart's 1943 writings on the power of X-ray technology, and to explore how his writing might be used as a tool for archival analysis that embraces queer (re)visions: "The X-ray device allowed for the tracing of a forgotten narrative. Even without the hint of a memory to assist in its detection, the X-ray responds to an unanswered question from the past" (p. 183). The various (re)visions of Alan Hart's life, while flawed and incomplete, have intermingled with my affective relationship with the object of the photo album, aiding in a deep sense of queer belonging and existence.

As I followed the unfolding of Hart's surgical transition in the public sphere, reading clippings from a regional Oregon newspaper, the Albany Daily Democrat, I gained insight into the collective mainstream cultural shifts surrounding sex and gender roles erupting from the impacts of WW1. This small-town newspaper was the sole medium of collective communication in Albany, Hart's hometown. In 1917, an article honoured Hart's academic accomplishment of receiving a medical degree from the Oregon State Medical School of Portland. Hart's social, economic, and political positions granted him the rare ability to understand and guide the surgical and social transformation necessary for his well-being and autonomy. Hart was raised a white settler on the lands of the Kalapuya People. He was assigned "female" at birth, but as an heir to monetary wealth with access to academic education, he was able to wear attire that suited him in front of friends and family from an early age. He lived in a milieu where in 1918 some professed that "there is nothing wrong with wearing male attire in a hospital", no more "than in wearing it in a factory, laundry or workshop, as hundreds of thousands of women are now doing in America, England and France" ("Dr. Hart does work", 1918).

Early in 1918, the Albany Daily Democrat published two exposés on the topic of Hart's surgical transition. This was due to a former classmate and colleague's recognition and disclosure of Hart's former identity to the medical establishment in which they were both attendants. The first article reads as a hastily composed gossip column, while the latter provides the reader with 
International Journal of Child, Youth and Family Studies (2021) 12(3-4): 55-73

direct quotes from Dr. Hart as he spoke unequivocally of his surgery, his name change, and the reasons for both. In that article, titled "Dr. Hart Explains Change to Male Attire - Real Identity Discovered and Proof Held; Truth Beyond Question" ("Dr. Hart explains", 1918), Hart is quoted as stating, "I have been happier since I made this change than I have ever been in my life, and I will continue to live this way as long as I live" (p. 1). As the interview continued Hart went on to say, "There can be no dual sex in a person. It is either one or the other" (p. 1). This statement does not undermine or detract from the initial and growing sense of empowerment flourishing in the queer ancestral connection that has taken place within me. Seeing beyond the latter part of this statement, there is a place in me that allows this to exist in the time, space, and place that it was made while understanding the complexity of dialoguing with archived materials.

\section{Impact and Implications}

The U.S.-based Human Rights Campaign (n.d.) reported that at least 44 trans and gendernonconforming people were murdered in the United States in 2020, the highest number reported since the organization began monitoring data in 2013, with Black and Latinx trans women disproportionately represented (Human Rights Campaign, n.d.). Similarly, in their study of future perspectives of 16 transgender and gender-nonconforming youth and their families, Katz-Wise et al. (2017) noted the detrimental impacts that high rates of discrimination and violence have on transgender children and youth, as well as their adult counterparts. However, key to this data analysis is the vital recognition that:

Although transgender individuals are disproportionately subject to adversity, transgender youth who receive higher levels of support from their families have been shown to experience better mental health outcomes, including lower likelihood of engaging in nonsuicidal self-injury, lower rates of suicidal ideation, fewer suicide attempts, fewer depressive symptoms, a decreased sense of burdensomeness stemming from the youth's transgender identity, higher selfesteem, and higher levels of life satisfaction (Simons et al., 2013; Travers et al., 2012; Veale et al., 2015). (Katz-Wise et al., 2017, p. 28)

With the intent to "de-pathologize emotional distress" that LGBTQ+ youth in their U.K. study had experienced, Elizabeth McDermott et al. (2019) focused on LGBTQ+ youth's mental health and its intersection with family relationships using a "relationship-oriented perspective" (p. 179). McDermott et al.'s discussion placed the onus on the family collective rather than the individual and, in doing so, recognized that the norms and expectations of heteronormativity in a family can take on the function of "levels of heteronormative surveillance" (p. 191). The authors described how the "data suggest the ongoing process of becoming an autonomous queer individual that did not fit with heteronormative family expectations created difficulties/tensions in belonging to their families, and for some it threatened a secure and safe home and was damaging to mental health" (p. 187). 
International Journal of Child, Youth and Family Studies (2021) 12(3-4): 55-73

The initial dearth of my queer archival knowledge can be contextualized as reflecting the legacy of white supremacist, heteropatriarchal, settler-colonialism that has sought to uphold the economic, political, and social power relationships that sustain these constructs as normative and ideal. The tactics for controlling bodies and behaviours through codifying sex, gender, and sexuality are intertwined, and relational to a person's multiplicity of being. The scripts and codes that a person is compelled to align with and agree to meld aspects of identity along spectra of skin colour, cognitive functioning, bank statements, physical abilities, language, and many others so as to stratify power and uphold monetarily wealthy, white, able-bodied, cisgendered, patriarchal formations. It has only been in the last few years that a critical awareness of regional place, land, and history has come to the forefront of my consciousness, reflecting a new understanding of the white privilege that has allowed me to remain ignorant. This kindling of queer (re)visions of past, present, and future has prompted a deeper recognition of the ways my lack of attention and respect to metaphysical and biological ancestry has been a symptom of the continuation of whitesupremacist patriarchy. I am in a continual process of unlearning the ways of being that maintain these interlocking systems of oppression.

\section{Critical Regional Place, Land, and History}

In this year 2021, in the region of the Pacific Northwest Coast, the toxicity of late-stage capitalism permeates the air. Within a short time, governments have declared a series of sometimes overlapping states of emergency. In early March of 2020, the World Health Organization declared the novel coronavirus disease (COVID-19) a pandemic, and many nation-state borders hurriedly closed. The international ferry that brought me to the lands of the Songhees, Esquimalt, and WSÁNEĆ peoples to study at the University of Victoria in British Columbia, Canada, sits docked indefinitely in Port Angeles in Washington, USA on the lands of the S'Klallam peoples. The city around the harbour that shelters this boat is built upon the desecrated site of the čix ${ }^{w i}{ }^{\prime}$ con (Tsewhit-zen) village. This village dated back as far as $750 \mathrm{BC}$; it was destroyed nearly 100 years ago by white settlers to make way for a lumber mill (Valadez, n.d), one of many built in the area for the purpose of turning old growth trees, larger than any person now living will ever see again, into raw material - into product, into profit. This drew many more settlers to the area over the years, including my maternal grandparents, causing the displacement and cultural genocide of the S'Klallam peoples and the despoliation of the surrounding lands and waters.

\section{(Be)Longing}

Though it is painful to contemplate, the toxic symptoms of the multilayered enforcement of heteronormative patriarchal beliefs have been infused into my family of origin. In young adulthood, my repressed queer sexual desires became imbued with a strategy for inner emotional freedom that used copious amounts of alcohol to allow me to touch moments of bliss that erupted from complicated and messy yearnings. The shame that surfaced after the hangovers, alongside my budding alcoholism, brought me to a decision to move away from my family of origin and my hometown and to live alone in a small studio apartment a few blocks from the Capitol buildings in Olympia, Washington. While refraining from alcohol during this time as I attended community 
college, a space was made for me to open to the idea that I am safe to feel desire outside the scripts of heteronormativity. It may very well have taken a bit longer had it not been for me stumbling upon and taking an elective course, "Diverse Sexualities and Cultures", in my first fall term.

The "coming-out" process with friends and family (initiated at the time with a selfidentification as a lesbian) was weird and uncomfortable, and remains so to this day. It is telling that a close friend responded to my coming out with, "You don't want to be a boy though, right?", to which I quickly responded, "Of course not." It is only now, in my early thirties, having been sober from alcohol for going on 8 years, having accessed mental health resources for most of my life, that I am able to see that interaction in the fulness of its meaning (as presently understood). This clarity is tied to the path that took me from my hometown to places where 2SLGBTQIAA+ people had been able to carve out communities in sites of mainstream cultural support, such as addiction support groups. Olympia was my springboard into Portland, Oregon, where for 10 years I (re)claimed (be)longing and "solid comfort". I moved to Portland on a whim with a friend I had met at summer camp when I was 9 years old, both of us having become camp counsellors in our teenage years; our friendship had grown to the point that by now we were "camp family" — chosen family. A few months later, another former camp counsellor joined us, becoming the third roommate in a two-bedroom tiny box of a condo. He, a gay, white, cis male, and she, a straight, white, cis female, had known each other since infancy; their familial bonds were already strongly woven. Soon enough we found a home further into the city, 100 years old with hardwood floors, a fireplace, and a big yard to build garden beds in.

That home lasted for 10 years. It would not have done so had I not succeeded in relinquishing alcohol through community support, particularly through finding 2SLGBTQIAA+ embracing spaces. Gopinath (2005) noted that "queer diasporic cultural forms suggest alternative forms of collectivity and communal belonging that redefine home outside of a logic of blood, purity, authenticity, and patrilineal descent" (p. 187). In Portland I found safety and support, navigating alternative ways of being that allowed me to reconsider opening to the child I was before the internalized shame and stigma of "acting like a boy", a pattern that progressed from wearing gender-ambiguous clothing in the early 1990s to a deeper body language and behaviour that made people question if my single mother had four sons instead of three. Being the youngest child in the family with three older brothers it was often assumed that I was emulating their behaviour, refusing to wear dresses once old enough to protest. I vividly remember reaching the summer of third grade and learning that how I wanted to dress, play, and be in the world would make me a target of ridicule by friends, family, and strangers. The triggering incident was a forced haircut to deal with persistent head lice. The cultural signifier allowing others to categorize me as female was removed. One of my aunts gave me the haircut at the request of my mother and both still regret the decision. In my heart it feels as though their regret does not stem from them taking away my right to selfautonomy, to choose the length and style of my hair, but instead comes from their own embarrassment and shame upon seeing clearly that - god forbid - I embodied my desire (in dress-up role play with friends, Halloween costumes, and the everyday) to be a boy. This shame 
and embarrassment were passed on to me and led to a desire to pass as a girl, a desire for puberty to change my flat chest into breasts so that the double-takes, stares, and weaponizing of my appearance would end. I am still in the process of unravelling these internalized complexities.

In this writing thus far, these travels and transformations appear to be linear, binary, and wholly positive in direction; however, the intricate messiness of my journey of seeking to (re)claim solid comfort and inner (be)longing is deeper than that. The multiple dislocations and ruptures that have occurred in my life over time have shifted my perceptions and conceptualizations of home and belonging. I am blessed to have a mother who over the years has moved through stages of acceptance and understanding in relation to my queerness, always striving to love and support me as best she is able. Simultaneously, I continue to reaffirm a boundary of unilateral severance with my biological father, who has consistently demonstrated his inability to respect these enforcements, belligerently affirming his apparent prejudices and ignorance. Sadly, these toxic beliefs and behaviours have splintered my biological family of origin; I shelter in levels of avoidance, now preferring silence over correspondence.

\section{SLGBTQIAA+ Children, Youth, and Families}

Tracing the toxicity of settler-colonial ideologies (patriarchy, heteronormativity, white supremacy, etc.), using this queer archival autoethnographic methodology, I have attempted to briefly lay bare the scripts and tactics of conformity in the settler-colonial United States regarding sexuality and gender. In the 21 st century, there still persist blaring reverberations of proclamations made from church pulpits in the 15 th century regarding life, land, and sovereignty. In our current epoch, people of diverse sexualities and genders remain systemically and interpersonally marginalized and oppressed, and targets of multilayered violence. Once again, the Human Rights Campaign has rung the alarm for the United States: by the first half of March 2021, 82 antitransgender bills had been filed in state legislatures since the beginning of the year, already eclipsing the highest number ever filed in a single year (Ronan, 2021). The purposes of these proposed laws include enacting discrimination against trans and nonbinary young people in the form of:

barring or criminalizing healthcare for transgender youth, barring access to the use of appropriate facilities like restrooms, restricting transgender students' ability to fully participate in school and sports, allowing religiously-motivated discrimination against trans people, or making it more difficult for trans people to get identification documents with their name and gender. (American Civil Liberties Union, 2021)

Individuals, families, and communities grapple with the resulting stress, trauma, and violence these tactics and scripts incite. It is vital that we as guardians of children and youth ensure their legal protection and autonomy while also empowering their queer ancestral consciousness. We as gender and sexually diverse people have existed across time and have cultivated belonging within ourselves, alongside others, and among community that is forever beyond the regimes of patriarchy. Our lives have been, are, and will be far more vibrant than the limitations of archival 
practices that show the lineage of legal persecution, dimmed in the shadow of oppression and violence. We are more than the collective strength of our resilience and resistance to erasure. 2SLGBTQIAA+ children, youth, and families deserve an illustration of the solid comfort that comes from belonging with oneself through the process of queering our collective consciousness and ancestral belonging across past, present, and future.

Navigating these archival realms, initially seeking to actualize the origins and personhood of the photo album's creator, has illuminated for me an entanglement of ancestry, identity, and place that embodies a transtemporal "rhizome" (a messy, multitudinal, and interconnected ancestral consciousness). During these uncertain and precarious times, navigating the unknown, yet-to-beshown, waiting-to-be-remembered ways of being, I am anchored in a growing sense of safety and belonging. I turn to the altar in my home where I have compiled found antique photographs of queer ancestors in the comfort of each other's presence, including "Solid Comfort". On my wall, I shield my home through honouring with images Joan of Arc, "transvestite and heretic" (Evans, 2013), and Grace Harper, a fictional super-soldier of the resistance sent back from 2046 to 2020 to protect her queer lover in the movie Terminator: Dark Fate (Miller, 2019). In my daily life, I continue to honour and cultivate these queer ancestral connections. 
International Journal of Child, Youth and Family Studies (2021) 12(3-4): 55-73

\section{References}

American Civil Liberties Union. (2021). Legislation affecting LGBT rights across the country. https://www.aclu.org/legislation-affecting-lgbt-rights-across-country

Assembly of First Nations (2018). Dismantling the Doctrine of Discovery. https:/www.afn.ca/wp-content/uploads/2018/02/18-01-22-Dismantling-the-Doctrine-ofDiscovery-EN.pdf

Baker, D. J. (2013). Creative writing praxis as queer becoming. New Writing, 10(3), 359-377. doi:10.1080/14790726.2013.811265

Boag, P. (2011). Re-dressing America's frontier past (1st ed.). University of California Press. https://www.jstor.org/stable/10.1525/j.ctt1pnk86

Bronski, M. (2011). A queer history of the United States. Beacon Press.

Cifor, M. (2016). Affecting relations: Introducing affect theory to archival discourse. Archival Science, 16(1), 7-31. doi:10.1007/s10502-015-9261-5

Daniszewski, J. (2020). Why we will lowercase white [Announcement]. AP: The Definitive Source. https://blog.ap.org/announcements/why-we-will-lowercase-white

Deo, M. E. (2021). Why BIPOC fails [Essay]. Virginia Law Review Online, 107, 115-142.

Devereaux, E. (2010) Doctor Alan Hart: X-ray vision in the archive. Australian Feminist Studies, 25(64), 175-187, doi:10.1080/08164641003762479

Doctrine of Discovery. (2021). Law. Indigenous Values Initiative and the American Indian Law Alliance. https://doctrineofdiscovery.org/law/

Upstander Project. (2021b). Doctrine of discovery: Summary. https://upstanderproject.org/firstlight/doctrine

Dr. Hart does work in male attire: Publicity given well-known Albany girl causes disgust of home folks. (1918, February 8), Albany Daily Democrat, p. 4.

Dr. Hart explains change to male attire: Real identity discovered and proof held; truth beyond question. (1918, March 26). Albany Daily Democrat, p. 1. https://www.newspapers.com/clip/16773780/albany-daily-democrat/

Evans, A. (1978). Witchcraft and the gay counterculture: A radical view of Western civilization and some of the people it has tried to destroy (2013 ed. published by feral death coven clandestinity). Fag Rag Books. 
International Journal of Child, Youth and Family Studies (2021) 12(3-4): 55-73

Federici, S. (2004). Caliban and the witch: Women, the body and primitive accumulation (1st ed.). Autonomedia.

Gill-Peterson, J. (2018). Histories of the transgender child. University of Minnesota Press.

Glenn, E. N. (2015). Settler colonialism as structure: A framework for comparative studies of U.S. race and gender formation. Sociology of Race and Ethnicity, 1(1), 52-72. doi:10.1177/2332649214560440

Gopinath, G. (2018). Unruly visions: The aesthetic practices of queer diaspora. Duke University Press. doi:10.2307/j.ctv11cw9dq

Greenberg, J. H. (2016). The Doctrine of Discovery as a doctrine of domination. Journal for the Study of Religion, Nature and Culture, 10(2), 236-244. doi:10.1558/jsrnc.v10i2.28942

Human Rights Campaign. (n.d.). Fatal violence against the transgender and gender nonconforming community in 2020. https://www.hrc.org/resources/violence-against-the-transand-gender-non-conforming-community-in-2020

Katz, J., (1976). Gay American history: Lesbians and gay men in the U.S.A.: A documentary. Crowell.

Katz-Wise, S. L., Budge, S. L., Orovecz, J. J., Nguyen, B., Nava-Coulter, B., \& Thomson, K. (2017). Imagining the future: Perspectives among youth and caregivers in the trans youth family study. Journal of Counseling Psychology, 64(1), 26-40. doi:10.1037/cou0000186

McDermott, E., Gabb, J., Eastham, R., \& Hanbury, A. (2019). Family trouble: Heteronormativity, emotion work and queer youth mental health. Health, 25(2), 177-191. doi:10.1177/1363459319860572

Miller, T. (Director). (2019). Terminator: Dark Fate [Film]. Tencent Pictures, Skydance Media, Paramount Pictures, Lightstorm Entertainment, \& Twentieth Century Fox.

O’Donnell, S. J. (2020). Witchcraft, statecraft, mancraft: On the demonological foundations of sovereignty. Political Theology: The Journal of Christian Socialism, 21(6), 530-549. doi:10.1080/1462317X.2020.1759278

Perry, I. (2018). Vexy thing: On gender and liberation. Duke University Press. https://www.jstor.org/stable/j.ctv11cw534

Rodriguez, E., Shofer, S., Harter, M., \& Clark, N. (2017). First guiding process: Problematizing what you know for new-self insight. In S. A. Hughes \& J. L. Pennington (Eds.), Autoethnography: Process, product, and possibility for critical social research (pp. 58-87). SAGE. https://www-doi-org.ezproxy.library.uvic.ca/10.4135/9781483398594 
International Journal of Child, Youth and Family Studies (2021) 12(3-4): 55-73

Ronan, W. (2021, March 13). Breaking: 2021 becomes record year for anti-transgender legislation [Press release]. Human Rights Campaign. https://www.hrc.org/pressreleases/breaking-2021-becomes-record-year-for-anti-transgender-legislation

Rowe, D. D. (2017). Beyond the talk-back: Performing autoethnography and the functions of critique. International Review of Qualitative Research, 10(3), 283-290. $\underline{\text { doi: } 10.1525 / \text { irqr.2017.10.3.283 }}$

Shoemaker, D. (2013). Autoethnographic journeys: Performing possibilities/utopias/futures. In S. Holman Jones, T. E. Adams, \& C. Ellis (Eds), Handbook of autoethnography (pp. 517537). Left Coast Press.

Valadez, J., Watson-Charles, C., \& Francis, B. (n.d). Tse-whit-zen. Lower Elwah Klallam Tribe. https://www.elwha.org/culture-history/tse-whit-zen/

Woman lives as a man. (1917, August 3). The Tacoma Times, p. 1.

Younging, G. (2018). Elements of Indigenous style: A guide for writing by and about Indigenous peoples. Brush Education. 